\title{
Género, incesto e identidad: una aproximación antropológica al cine de rumberas en México
}

\section{Francisco de La Peña Martinez ${ }^{1}$ Escuela Nacional de Antropología e Historia (México)}

Resumen: El objeto de este ensayo es proponer un análisis antropológico del cine. Centrándose en el caso específico del cine mexicano de la época de oro, se aborda uno de sus géneros más destacados, el cine de rumberas. Puede reconocerse en la narrativa propia de este género, en la que el personaje de la prostituta es protagónico, la presencia de mitos y fantasmas masculinos relacionados con la identidad femenina, y en los cuales el incesto de segundo tipo aparece como un motivo recurrente.

Palabras clave: antropología; cine; incesto. 


\title{
Gender, incest and identity: an anthropological approach rumberas' movies in Mexico
}

\begin{abstract}
The purpose of this paper is to propose an anthropological analysis of cinema. Focusing on the specific case of Mexican cinema's golden age, it addresses one of the most prominent genres, the rumbera's movies. It can be seen in the very narrative of this kind, in which the character of the prostitute is leading, the presence of male ghosts and myths related to feminine identity, and in which the incest of the second type appears as a recurring motif.

Keywords: anthropology; cinema; incest.
\end{abstract}

\section{Gênero, incesto e identidade: uma aproximação antropológica ao cinema de rumberas no México}

Resumo: O objetivo deste trabalho é propor uma análise antropológica do cinema. Centrando-se no caso específico da idade de ouro do cinema mexicano, aborda um dos gêneros mais proeminentes, o cinema de rumberas. Pode ser visto na narrativa deste gênero, em que o papel da prostituta é central, a presença de fantasmas e mitos relativos à identidade do sexo masculino e feminino na qual o incesto do segundo tipo aparece como um motivo recorrente.

Palavras-chave: antropologia; filmes; incesto. 


\section{Escena original y cine}

El origen de las cinematografías nacionales es un tema que inevitablemente evoca la lectura de lo cultural en clave clínica o psicoanalítica, pues es muy común encontrar en las tradiciones fílmicas la existencia de temas tabú o sometidos a represión, o bien temas recurrentes y compulsivos que vuelven una y otra vez a la manera de un síntoma obsesivo, o bien temas que son llevados a la pantalla pero a condición de someterlos a un proceso de censura o desfiguración que termina por volverlos inocuos.

Shlomo Sand nos recuerda en su trabajo sobre el cine y la política en el siglo veinte el ejemplo de la cinematografía francesa en relación al caso Dreyfus y al célebre combate que Emile Zola emprendió contra el alto mando militar francés en defensa del capitán del ejército, de origen judío, acusado injustamente de espionaje y traición a la patria. La tradición cultural francesa, que se precia de su espíritu democrático y tolerante, abierto a la crítica y las libertades, en este caso ha dado muestras de una más que sintomática autocensura. En efecto, el acontecimiento en cuestión (en el que la verdad triunfo, varios jefes militares tuvieron que retirarse y Dreyfus fue reinstalado en su cargo) coincidió con el nacimiento del cine en Francia, y motivó la realización de una serie de películas más o menos exitosas (una de ellas realizada por Méliès) a fines del siglo XIX y comienzos del XX. En todas ellas se presentaba a Dreyfus como una víctima inocente de la incompetencia y el anti-semitismo de los altos mandos del ejército francés, representados como villanos innobles.

A raíz de la primera guerra mundial, sin embargo, y arguyendo la necesidad de unidad nacional, el gobierno francés prohibió la exhibición o la producción de cualquier filme relacionado con el caso Dreyfus, decisión que no cambió al finalizar la guerra y que sorprendentemente se extendió desde esa época hasta la década de los setentas. Durante todo ese tiempo, películas sobre el tema realizadas en Inglaterra o Estados Unidos, como la conocida película de William Dieterle La vida de Emile Zolá (1937) no fueron exhibidas en Francia y solo recientemente han podido ser conocidas. Así, el affaire Dreyfus, como si se tratara de un evento traumático insoportable, se convirtió en el gran ausente del cine francés, una suerte de secreto de familia (del que todos saben pero nadie habla) que nos revela muchos de los conflictos (racismo, soberbia, autoritarismo, anti-semitismo, rigidez) que atraviesan al universo cultural francés (SAND, 2010).

Es posible que en todas las tradiciones cinematográficas existan temas prohibidos. En el caso de México, tal vez el tema tabú más evidente sea la conquista de México por parte de los españoles, evento traumático por antonomasia que nadie en la industria del cine nacional se ha atrevido a llevar a la pantalla de una manera explícita y frontal (curiosamente, ni siquiera los cineastas extranjeros, en apariencia menos implicados culturalmente, lo han intentado). Pero si existen temas prohibidos que nos revelan mucho sobre la identidad de una cinematografía, también son reveladores los temas que están en el origen de una tradición fílmica.

Si el western o el cine policiaco constituyen géneros fundacionales que permean buena parte del imaginario fílmico norteamericano ¿Porque el cine 
mexicano tiene en sus orígenes películas como Santa (1931), La mujer del puerto (1933) o La mancha de sangre (1937), que inauguran un género local que ha tenido siempre mucho éxito y un amplio desarrollo, el cine de prostitutas? En efecto, el melodrama de prostitutas, junto al cine indigenista, el cine de la revolución, la comedia ranchera, el cine de luchadores, y más recientemente el cine de narcotraficantes, han conocido una popularidad y un arraigo tal que se han convertido en géneros distintivos del cine mexicano. En contraste con el cine de México, el cine de prostitutas (también llamado en este país cine de cabareteras, de rumberas, de exóticas, de ficheras o cine erótico) ocupa un lugar relativamente secundario en el imaginario fílmico norteamericano y europeo, en donde destacan pocos films de este tipo y unas cuantas figuras, como Dietrich en El Ángel Azul (1930) y Venus Rubia (1932) de Von Sternberg, o Louise Brooks en Lulú (1928) y Diario de una mujer perdida (1929) de Pabst.

El arraigo de este género en México responde a diversos factores específicos que están ausentes en otros países. El éxito que tuvo en su momento Santa, la novela del escritor Federico Gamboa que da origen al género cinematográfico, un auténtico best seller literario de la época porfirista y prerevolucionaria, que describía los infortunios que llevan a una joven e ingenua mujer a ser repudiada por su familia y a convertirse en una prostituta y un personaje cínico y desgraciado, explica solo en parte el éxito de su adaptación fílmica. Es sabido que existen cuatro versiones fílmicas de Santa producidas en diferentes épocas, de las cuales tres son en blanco y negro y una en color, una en cine mudo (Luis G. Peredo, 1918), y tres en cine sonoro (MORENO, 1931; NORMAN FOSTER, 1943; GÓMEZ MURIEL, 1968). Pero igualmente existen tres versiones de La mujer del puerto, el otro gran film fundador del género referido (ARCADY BOYTLER, 1933; EMILIO GÓMEZ MURIEL, 1949; ARTURO RIPSTEIN, 1991)

Si ello es revelador del impacto de esta clase de películas en el gusto de los mexicanos, la fascinación del público mexicano por las historias de mujeres prostitutas no es gratuito, y en realidad tiene profundas raíces psicológicas que remiten a los mitos fundadores de la mexicanidad, entre los cuales las figuras femeninas de la Malinche, de la Llorona o de "la chingada" (que tienen como su contraparte a la figura de la Virgen de Guadalupe) destacan por su pregnancia simbólica.

La Malinche es la Eva mexicana o la María Magdalena local, y personifica en el imaginario nacional a la mujer nativa que traiciona y desprecia a los suyos y se entrega voluntariamente al invasor extranjero, lo que la degrada y la equipara a la figura de la prostituta. Por su parte, ser un "hijo de la chingada" en la mentalidad mexicana significa en buena medida ser hijo de una mujer que ha sido víctima de abuso sexual o que se ha visto llevada a prostituirse, y más en general, remite al fantasma de las mujeres indígenas que fueron sexualmente forzadas por los conquistadores europeos y de las que descienden los mexicanos mestizos.

La Llorona, finalmente, descrita como una fantasmal mujer que vaga por los caminos llorando y reclamando a sus hijos muertos, remite tanto a la figura de la Malinche² como a ciertas deidades femeninas prehispánicas (Cihuacoatl,

${ }^{2}$ La leyenda de la Llorona cuenta la historia de una mujer (criolla o mestiza en algunas versiones, indígena en aquellas que la asocian con la Malinche) enamorada, traicionada y abandonada por su amante español, que en venganza habría cometido infanticidio, acción que la condena a volver de ultratumba arrepentida y avergonzada a llorar su tragedia y a traer desgracias a los vivos. 
Xtabay) asociadas al inframundo, la lujuria y la muerte, elementos que explican que en algunas versiones ella sea descrita como una mujer muy atractiva y sensual que seduce y enamora a los hombres para después destruirlos.

La escisión psíquica que Freud describe como un rasgo característico de los hombres neuróticos, que los lleva a oponer los sentimientos tiernos a los eróticos, haciéndolos corresponder con dos figuras de la feminidad enfrentadas, la virgen y la puta, encarnadas por la esposa y la amante, o la madre y las "otras", o las hermanas y el resto de las mujeres, encuentra en el imaginario colectivo mexicano su equivalente en la oposición entre la Virgen de Guadalupe y la Malinche, polos extremos y personificaciones de la buena y la mala mujer. Y si la Virgen de Guadalupe, para los mexicanos la representación de la madre ideal, bondadosa y misericordiosa, es una figura que en el cine nacional tiene una presencia notable, en donde toma la forma de la madre mártir, abnegada y sacrificada, la Malinche y sus sucedáneos míticos encarnan a las mujeres de la vida nocturna (impuras, peligrosas y de poco fiar) que la prostituta personifica inmejorablemente.

La popularidad del cine de prostitutas en México no es ajeno a este trasfondo cultural, y en cierto sentido podríamos considerarlo como un género que pone en escena el arquetipo de la madre mala o de la mujer profana (la sabiduría popular describe a los mexicanos como "hijos de la chingada" o "hijos de la Malinche"). Incluso el hecho de que Santa sea el nombre del personaje de la prostituta que funda el género fílmico en cuestión, subraya la confusa frontera que separa a la Virgen de la Puta, el carácter ambiguo y ambivalente de ambas figuras, y revela los resortes fantasmáticos de su imantación libidinal.

A este respecto, Roger Bartra ha propuesto el término de Chingadalupe para referirse al arquetipo femenino mexicano y para destacar la dualidad y la ambivalencia simbólica que lo caracteriza, en donde se combinan de un lado la pasión romántica tormentosa y del otro el amor filial cristiano (1987: 222).

Ahora bien, si los géneros cinematográficos están condicionados en parte por arquetipos y estructuras mentales de larga duración, también responden a determinaciones más coyunturales y cambiantes, como las que tienen que ver con las representaciones de género y los estereotipos de lo femenino y lo masculino en la modernidad. Como señala Ramirez Berg, a propósito del cine mexicano, si en general los estereotipos de lo masculino se asocian en él a lo activo, lo móvil y lo público, los estereotipos de lo femenino se asocian con lo opuesto, es decir, lo inactivo, lo inmóvil y lo pasivo, estando las mujeres por ello limitadas al espacio del hogar, el convento o el burdel (Ramírez Berg, 1992: $56)^{3}$.

Existe un vasto repertorio de tipos femeninos en el cine mexicano clásico entre los cuales podemos mencionar los de la madre, la esposa, la hermana, la novia, la suegra, la amante, la abuela, la solterona, la monja, la secretaria, la prostituta o la sirvienta, tipos que en general suelen situarse en alguno de los extremos que oponen a la mujer decente y la mujer indecente, la buena y la mala mujer, la mujer sumisa y la rebelde.

\footnotetext{
3 Existe una estrecha relación entre los estereotipos de lo masculino y de lo femenino, los cuales reflejan la forma que toman y la evolución que han seguido las relaciones de género en el cine mexicano. A diferencia de la mujer, quien es representada en el cine mexicano de la época de oro como un sujeto dependiente del destino y la fatalidad, débil e impulsivo, el hombre es retratado como un sujeto que dispone de una mayor libertad de elección y de pensamiento, así como de una fuerza de voluntad y de un carácter más firme que le permiten modificar su medio y enfrentar las situaciones y los conflictos de una manera más crítica y confiada.
} 
Si la madre suele ser representada como una mujer sacrificada $y$ desinteresada, paciente, generosa y buena, la hermana es una extensión de la figura materna en el orden doméstico. Como señala Oroz, en muchos filmes la hermana suple a la madre cuando ésta muere, respeta y admira al hermano, cuida y se sacrifica por su hermana o hermano menor como si fuera su madre. La hermana es también como la novia, una mujer pura cuya moral es incuestionable, a quien hay que cuidar y de quien debe protegerse la honra (es decir, la virginidad). La esposa, por su parte, es la responsable por la educación de los hijos, una mujer fiel, obediente y tolerante con su esposo, y en muchos casos, una esposa-niña para su marido, ingenua e inocente como la novia (Oroz, 1990).

Como señala Tuñon, la mujer en el cine mexicano de la época de oro se sitúa entre alguno de dos polos simbólicos contrapuestos: el de la mujer nutricia y el de la mujer devoradora, figuras ambas que remiten a una oralidad exaltada que puede ser pasiva o activa, purificadora o pervertidora. La madre sacrificada, la hermana casta, la novia pura o la esposa fiel se oponen a la mujer indecente (prostituta, amante o rumbera) que amenaza los tabúes sociales, mantis religiosa que despierta los temores masculinos más arcaicos, mujer sin escrúpulos cuya sexualidad animal lleva a los hombres a la perdición (Tuñon, 1998). En contraste con la hermana, la madre, la novia o la esposa, que suelen hablar correctamente, armonizar y preservar el orden, recogerse el pelo, no usar escotes o vestir discretamente, la mala mujer, la mujer devoradora, viste provocativamente y utiliza sus atractivos físicos abiertamente, emplea un lenguaje vulgar y directo, destruye y desequilibra todo a su paso ${ }^{4}$.

En este contexto, la figura de la prostituta es un estereotipo que cumple una función simbólica esencial en el imaginario fílmico mexicano. En la medida que representa la sexualidad transgresiva, una sexualidad al margen de las constricciones de la familia monógama tradicional (que permite definir por contraste los límites de la feminidad moralmente aceptable) la cabaretera, la mujer "perdida", es un personaje liminal que a la vez cuestiona la doble moral del sistema patriarcal y contribuye a su reproducción, que encarna a un tipo de mujer empoderada y rebelde pero también victimizada y degradada, cuya conducta pecaminosa subvierte las jerarquías establecidas pero justifica también su sumisión al poder masculino. El aura que emana de este personaje, la fascinación que ejerce y la centralidad que tiene en la cinematografía mexicana nos obligan a interrogarnos sobre el significado cultural y psicológico de este símbolo dominante.

\section{El cine de rumberas y sus componentes}

El cine mexicano de prostitutas nace en los años treinta y tiene su época de oro en la segunda mitad de la década de los cuarenta y la primera mitad de los cincuenta. Entre las divas del cine de cabareteras destacan en especial las actrices cubanas (Ninón Sevilla, María Antonieta Pons, Rosa Carmina y Amalia Aguilar) pero también otras notables actrices como Meche Barba, Miroslava,

\footnotetext{
4 Existe una estrecha relación entre los estereotipos de lo masculino y de lo femenino, los cuales reflejan la forma que toman y la evolución que han seguido las relaciones de género en el cine mexicano. A diferencia de la mujer, quien es representada en el cine mexicano de la época de oro como un sujeto dependiente del destino y la fatalidad, débil e impulsivo, el hombre es retratado como un sujeto que dispone de una mayor libertad de elección y de pensamiento, así como de una fuerza de voluntad y de un carácter más firme que le permiten modificar su medio y enfrentar las situaciones y los conflictos de una manera más crítica y confiada.
} 
Andrea Palma, Lupita Tovar, Esther Fernández, Marga López, Leticia Palma, Sara Montiel o Tongolele. La mayoría de ellas fueron excelentes bailarinas o cantantes, mujeres-espectáculo y símbolos sexuales de varias generaciones de mexicanos.

Como muchos observadores han señalado, no por casualidad este género alcanzó su clímax durante el gobierno de Miguel Alemán, entre 1946 y 1952. En efecto, el boom del cine de cabareteras y prostitutas coincide con el mandato del primer presidente civil después de la Revolución de 1910, quien alienta una modernización acelerada acompañada de profundas transformaciones (urbanización, migración a la ciudad, desarrollo económico y crecimiento industrial, ampliación del sistema educativo, cambios sociales, culturales y en los roles de género) y en la cual se da un boom de la vida nocturna en México (AVIÑA, 2004).

De la Mora ha propuesto que la prostituta es en cierta forma la encarnación de todos los conflictos generados por este proceso, un agente social que expresa las ansiedades, los deseos y las contradicciones despertados por la modernización. Ella personifica el conflicto entre campo y ciudad (la joven provinciana o humilde que cae por distintas circunstancias en el cabaret o el prostíbulo y es orillada a la perdición y la marginalidad), entre tradición y modernidad (al transgredir las normas familiares y sexuales, al desafiar la moral burguesa, al compatibilizar la maternidad con el trabajo sexual) y es el icono más radical de la experiencia urbana (DE LA MORA, 2006).

El género en cuestión se distingue de otros géneros equiparables por la importancia que tienen el baile y la música en su narrativa (en la que el cabaret o el salón de baile son la encarnación de una suerte de paraíso musical, un reino exótico en el que predominan las coreografías inspiradas en los ritmos caribeños como la rumba y el son, el mambo, el danzón o el chachacha, la samba o la cumbia, pero también en los ritmos de medio oriente o de la polinesia) así como por su visión tremendista y llena de excesos dramáticos (fatalismo, maniqueísmo, énfasis en las pasiones y los impulsos, simplificación, redundancia y acumulación trágica, hiper-erotismo)5.

Del vasto corpus de películas de prostitutas, y a fin de llevar a cabo un ejercicio de lectura antropológica, centraremos nuestra atención en un número limitado de filmes, muchos de los cuales la crítica suele considerar como paradigmas del género. Si La Mujer del puerto y Santa son las que más destacan en los años treinta, para las décadas siguientes sobresalen filmes como La bien pagada (Alberto Gout, 1947), Cortesana (Alberto Gout, 1947), Salón México (Emilio Fernández, 1948), Revancha (1948), Perdida (Fernando A. Rivero, 1949), Aventurera (Alberto Gout, 1949), Hipócrita (Miguel Morayta, 1949), Coqueta (Fernando A. Rivero, 1949), Amor salvaje (Juan Orol, 1949), Amor de

\footnotetext{
5 Pueden distinguirse tres tiempos fuertes en el cine sobre prostitutas en México, que responden a condiciones históricas específicas y a modelos narrativos contrastantes. El primer período, que es en el cual hemos centrado nuestro análisis, es el que va de los años cuarenta a los años cincuenta, y está asociado al género melodramático, en el que la prostituta es generalmente una bailarina o cantante, no existen desnudos más que parciales, la sexualidad es implícita y las historias se despliegan en el mundo del cabaret y los prostíbulos. El segundo período se desarrolla a fines de los sesenta y la primera mitad de los años setenta y corresponde al género del cine erótico, basado en historias más o menos retorcidas que pueden ser dramáticas o en tono de comedia, no necesariamente asociadas al mundo del cabaret, y en el predominan los desnudos y las escenas sexuales explícitas. Destacan en este género actrices como Meche Carreño, Isela Vega, Maritza Olivares o Pilar Pellicer. El tercer período va de la segunda mitad de los setentas a inicios de los ochentas y corresponde al género de la comedia sexual o sexi-comedia. Conocido como cine de "ficheras", éste tipo de cine se caracteriza por los desnudos y las escenas sexuales, números de música tropical en ambientes de cabaret, historias románticas elementales y una comicidad basada en el albur y las palabras altisonantes. Sasha Montenegro y Jorge Rivero destacan como los íconos de éste cine, junto a una legión de comediantes y de voluptuosas desnudistas (Lyn May, Rossy Mendoza, Wanda Seux, Angélica Chaín, etc.)
} 
la calle (Ernesto Cortázar, 1949), La hija del penal (Fernando Soler, 1949), Un cuerpo de mujer (Tito Davidson, 1949), Victimas del pecado (Emilio Fernández, 1950), Sensualidad (Alberto Gout, 1950), En carne viva (Alberto Gout, 1950), Amor vendido (Joaquín Pardavé, 1950), El Suavecito (Fernando Méndez, 1950), Trotacalles (Matilde Landeta, 1951), Porque peca la mujer (René Cardona, 1951), Amor perdido (Miguel Morayta, 1951), Viajera (Alfonso Patiño, 1951), Aventura en Rio (Alberto Gout, 1952), Piel canela (Juan J. Ortega, 1953), As negro (Fernando Méndez, 1953), Amor y pecado (Alfredo B. Crevenna, 1955), Sucedió en México (Ramón Pereda, 1957).

Los títulos de estas películas revelan de una forma más que evidente la imagen que se busca proyectar de la protagonista de este género, ya sea enfatizando los rasgos de su personalidad, de su condición o de los ámbitos en que se desenvuelve. Existen en el cine de prostitutas y rumberas distintos tipos de matrices narrativas, algunas explícitas, situadas a nivel de los crono-tropos, los arquetipos y los estereotipos, y otras implícitas, que responden a fantasías y estructuras de naturaleza inconsciente. Entre las primeras podemos mencionar el caso de las locaciones, como el burdel o el cabaret (y en algunos casos la vecindad o el salón de baile), que son crono-tropos característicos que enmarcan el mundo de la agitada vida nocturna en la que se desarrollan la mayor parte de los melodramas de prostitutas, y que generalmente se oponen al tranquilo mundo diurno del hogar y la familia, el trabajo o la Iglesia.

En lo que toca a los tipos femeninos que las protagonistas de este género personifican, hemos mencionado el carácter ambiguo de las prostitutas fílmicas, mujeres connotadas positiva y negativamente, que pueden ser a la vez puras y corruptas, inocentes y malvadas, víctimas y verdugos. A este respecto, se pueden distinguir dos prototipos de la prostituta que se suceden y coexisten conforme evoluciona el género. Por un lado, la prostituta inocente que se mantiene virgen y pura en espíritu y que se ve llevada a pecar a causa de diversas circunstancias desafortunadas, una víctima del destino que en el fondo es una simple y buena mujer. Por otro lado, la prostituta cuya belleza y sensualidad la marcan de tal manera que se sirve de ellas de una manera autoconsciente para alcanzar sus fines, una heroína desafiante y ambiciosa que es menos victima que victimaria. Si el ejemplo del primer modelo es Lupita Tovar en Santa, Ninón Sevilla en Sensualidad encarna a la perfección el segundo modelo.

Toda una galería de tipos masculinos forma parte del modelo narrativo de esta clase de películas. Por ejemplo, en muchos filmes está presente la figura del enamorado secreto de la cabaretera, fiel y no correspondido, que es un aliado y protector de la protagonista: el compositor invalido enamorado de Meche Barba, representado por Fernando Fernández en Amor vendido; el matón guardaespaldas Rengo, en Aventurera, enamorado de Ninón Sevilla; el policía de crucero en Salón México, que cuida a Marga López; el compositor en Amor perdido (enamorado de Amalia Aguilar), el pianista ciego en las distintas versiones de Santa (el célebre Hipólito), en Coqueta y en Revancha (filmes en los que Agustín Lara encarna a este personaje, verdadero escudero de Ninón Sevilla) ${ }^{6}$.

\footnotetext{
${ }^{6}$ Las canciones del músico y compositor Agustín Lara ocupan un lugar vertebral en la construcción y en la exaltación de la mitología asociada al universo de las prostitutas, la bohemia y la vida nocturna en el cine mexicano. Con una poética romántica que recurre en muchos casos al lenguaje religioso del sacrificio y la redención, Lara crea una imagen idealizada de la prostituta como un icono que encarna la sensualidad, el glamour, el fatalismo y el infortunio femenino pero también el desafío a las convenciones y la denuncia de la hipocresía moral de la sociedad burguesa.
} 
Otro personaje recurrente en este género es el del hombre recto y justo, maduro y moral, que es devorado por la pasión erótica hacia una mujer joven e irresistible que lo convierte en un pelele sin dignidad, y que Rubén Rojo en Aventurera o Fernando Soler en Sensualidad han encarnado a la perfección. Otro tipo reconocible sería el del novio fiel y paciente que soporta estoicamente los vaivenes de la cabaretera hasta conseguir quedarse con ella, como el novio de Meche Barba en Cortesana, que recupera a su prometida después de que ésta incurre en mil y un desfiguros, o el novio de Meche Barba en Amor de la calle.

En fin, una figura emblemática e infaltable en el submundo del cabaret y los prostíbulos, es la del proxeneta pervertidor (chulo, cinturita o padrote) que explota y somete a su voluntad a la prostituta, el villano por antonomasia, abusivo y violento, que nadie encarnó mejor que Rodolfo Acosta en Victimas del pecado y Salón México, pero también Tito Junco como Lucio "el guapo" en Aventurera, Víctor Parra en El suavecito o Ernesto Alonso en Trotacalles, por solo mencionar algunos nombres.

La prostituta aparece en el cine casi siempre como una mujer sin familia y sin protección, sujeta al abuso de la policía y los proxenetas, asociada al mundo del hampa y de la violencia, una mujer que en muchos films es agresiva, impulsiva o vengativa. Como señala Tuñón, la figura de la mujer violenta y agresiva es una constante en esta clase de cine, en el cual "la mujer que ejerce el sexo aprende poco a poco las formas delegadas por género a los hombres: la fuerza, el lenguaje claro, el descuido de la prole" (Tuñón, 1998: 249).

En la fórmula consagrada del melodrama de cabaret, la mujer "perdida" está condenada a sufrir, a enfermar, a morir o a ser castigada, ya sea por la ley o por la naturaleza. Independientemente de que responda al modelo de la mujer seducida, abandonada y prostituida, como en Santa, que termina sus días enferma y en la miseria, o que se ajuste al modelo de la vampiresa que es destruida por las pasiones que suscita, como en La mujer del puerto, en todos los casos hay una suerte de sanción necesaria e inevitable.

Existen excepciones a esta regla, como lo ilustra el caso de Victimas del pecado, en donde Ninón Sevilla encarna a una prostituta que asume la maternidad de un niño abandonado por otra prostituta, conoce a un empresario que le da trabajo y la apoya, es asediada por el proxeneta padre de la criatura, a quien se ve orillada a asesinar, y una vez en la cárcel, recibe el indulto presidencial que le permitirá atender a su hijo adoptivo. En este film la prostituta es redimida gracias a la intervención del Estado y a su buen comportamiento como prisionera y como madre.

Allí donde sucede, en estos filmes el personaje de la cabaretera solo puede ser redimido o resignificar su trágico destino a condición de ser una mujer buena, prostituida pero espiritualmente virgen, que actúa noble $u$ honestamente, como en Salón México, donde Marga López encarna a una prostituta que paga la colegiatura de su hermana menor en un costoso internado y a quien oculta su actividad, o en Amor de la calle, en donde Meche Barba se ve obligada a trabajar en un cabaret para sacar de prisión a su hermano y a su novio, quienes al enterarse del hecho se sienten deshonrados por ella aunque después, al comprobar su buena intención, la perdonan y se reconcilian con ella.

Si este no es el caso, la cabaretera terminará invariablemente mal. Una de las metáforas más notables del sino trágico de la mujer "perdida" es la desfiguración. La desfiguración es una poderosa representación simbólica que está presente en distintas películas del género y que puede significar o un 
castigo o una suerte de marca de origen de la mujer "caída". En Amor Perdido, por ejemplo, la protagonista utiliza un antifaz que oculta la deformidad física que le provocó una explosión provocada por la mujer de su amante, un contrabandista que cree que ella lo abandonó y al final termina matándola. En Hipócrita un tipo mata por venganza al padre de Leticia Palma, un delincuente, y marca en la cara a ésta. Gracias a la ayuda de un compositor ella se hace una cirugía y queda bien del rostro, después de lo cual debuta como bailarina en un cabaret, con lo que se condena a un dramático destino.

En Piel canela Sara Montiel es una cantante de cabaret que tiene que cubrirse media cara con su pelo para ocultar la desfiguración que le provocó cuando niña una rata, por descuido de sus padres. Aquí también la cirugía remedia el problema aunque no evita el final trágico de la protagonista. En Sucedió en México María Antonieta Pons, tras un intento de suicidio por la infidelidad de su marido, queda desfigurada y es operada por un cirujano que le deja un nuevo rostro, lo que le permite convertirse en bailarina de cabaret.

La desfiguración puede tomar una forma derivada o indirecta, como en la película Cuerpo de mujer, cuya trama gira en torno a la historia de un lienzo de una mujer desnuda del que ha sido arrancado el rostro, y quien es una rumbera cuyos atractivos desatan fuertes pasiones entre los hombres que se la disputan, entre los cuales está el pintor del cuadro. Una curiosa variante de la desfiguración es la pérdida de la voz, como en el film Porque peca la mujer, en donde Leticia Palma es una billetera que vende a un malviviente un billete que lo vuelve rico, y este a cambio la convierte en cabaretera, aprovechando sus dotes para cantar. El compositor que la ama triunfa pero ella lo deja y prefiere irse con el rico delincuente. La policía detiene a éste y una vedette que es su amante hiere a la cabaretera dejándola sin voz. A causa de ello, ésta termina como prostituta pobre y enferma. El compositor, de vuelta de una exitosa gira, la busca hasta dar con ella en una miserable cantina pero solo alcanza a verla momentos antes de que muera.

Como puede apreciarse, el relato característico del cine de cabareteras comprende un conjunto de elementos estrechamente ligados: cronotopos que localizan las escenas primarias de este género, tipos y estereotipos que animan las relaciones entre los personajes así como elementos simbólicos diversos que poseen un significado explícito y relativamente accesible (modales, lenguaje, vestimenta, defectos físicos, etcétera).

\section{El incesto de segundo grado y las identidades inciertas}

Junto a estos elementos, sin embargo, en el cine de rumberas están presentes una serie de estructuras recurrentes, latentes y menos evidentes, que remiten al registro del inconsciente óptico del que habla Benjamin, un inconsciente que es el de una mirada masculina que pone en escena fantasías de género muy precisas. En ellas se proyectan imágenes de lo femenino que representan a la mujer como un objeto libidinal escindido e inestable, imágenes que interpelan fundamentalmente a un público muy específico de adeptos al género, que si bien comprende a las mujeres, en su mayoría es masculino.

La mujer es vista en estos filmes según perspectivas que son múltiples y complementarias: como dividida en dos (siguiendo el modelo de la oposición entre la santa y la puta, o la esposa y la amante), o como una persona con una identidad incierta o cambiante, que puede tomar distintas formas (doble 
identidad, ocultamiento de la identidad, cambio de identidad, ignorancia de la verdadera identidad, amnesia u olvido de la identidad propia, gemelidad). En un gran número de casos, y esto es de lo más significativo para la mirada antropológica, el cine de cabareteras hace manifiesta la condición liminal e indefinida de la mujer de "la mala vida" por medio de transgresiones sexuales que remiten al incesto consanguíneo tradicional pero especialmente al incesto de segundo tipo, estudiado por Françoise Héritier.

Para esta antropóloga, a diferencia del incesto clásico, en el que están involucrados en relaciones sexuales dos parientes de sexo opuesto que son considerados como consanguíneos o afines en grados prohibidos por la moral o la costumbre, en el incesto de segundo tipo se establece una relación triangular entre dos parientes consanguíneos del mismo sexo que comparten una misma pareja. Así, esta clase de incesto, en su forma más elemental, se establecería entre padre-hijo, madre-hija, hermano-hermano y hermana-hermana por intermedio de un mismo compañero sexual.

Heritier se interesó en aquellos tipos de prohibiciones sexuales que no afectan al matrimonio ni la reproducción, o que se sitúan más allá de ellos (ciertas formas de adulterio, el compadrazgo, el levirato y el sororato, la sodomia, la zoofilia, la necrofilia, la gemelidad) y sus análisis la llevaron a pensar la lógica simbólica del incesto en un sentido muy amplio y a plantear que el incesto de segundo tipo está en el origen de la prohibición del incesto del primer tipo y no a la inversa. Su propuesta es que la existencia del incesto de segundo tipo nos lleva a concebir la prohibición del incesto como un problema de circulación de fluidos de un cuerpo a otro, y que el criterio fundamental del incesto es el contacto, mezcla o yuxtaposición de humores idénticos.

Para esta antropóloga, la oposición entre lo idéntico y lo diferente constituye una matriz simbólica universal, fundada en lo que el cuerpo humano tiene de más irreductible, a saber, la diferencia entre los sexos, es decir, la diferencia entre lo masculino y lo femenino. De ella derivan las problemáticas de lo mismo y lo otro, lo uno y lo múltiple, lo continuo y lo discontinuo y en un plano menos abstracto, sistemas de valores basados en oposiciones como caliente-frío, claro-obscuro, seco-húmedo, pesado-ligero, a partir de los cuales se construyen las clasificaciones de los humores y substancias corporales (sangre, leche, semen, médula, carne, huesos) y el sistema que rige su circulación o la prohibición de ésta. En este contexto, la acumulación o el exceso de lo idéntico es incestuoso porque anula las diferencias y produce un peligroso desequilibrio simbólico, poniendo en entredicho la manera en que las sociedades construyen sus categorías de lo idéntico y lo diferente7.

Por ejemplo, es porque existe más substancia e identidad común entre un padre y su hijo que entre un padre y su hija que en ciertas sociedades la unión corporal de un hombre con la mujer de su padre o de su hijo puede ser considerada más dañina que la relación sexual entre un padre y su hija, dado que se piensa que la substancia del padre toca a la del hijo y recíprocamente, a través de la pareja común. Por esta misma razón se cree en otras sociedades que un hombre debe casarse con la hermana de su esposa muerta, dado que siendo hermanas que comparten la misma substancia, encontrará en ella a una 
excelente madre para sus hijos. Ya los textos de la antigua Sumeria condenan por incesto la unión de una madre y su hija con un mismo compañero sexual, y el Corán prohíbe las relaciones sexuales de un hombre con la hija de una mujer a la que haya tenido como pareja sexual.

Para Héritier, lo que todo esto demuestra es que la prohibición del incesto se funda en una dialéctica entre lo mismo y lo otro, lo idéntico y lo diferente, lo homogéneo y lo heterogéneo, en un orden de signos, clasificaciones, vínculos e intercambios que la transgresión sexual disuelve y desintegra, propiciando el desdibujamiento de los límites y el caos simbólico. El simbolismo de la diferencia sexual no solo condiciona la imagen del cuerpo (de la que dependen las concepciones sobre la procreación o sobre la relación entre las generaciones), no solo modela las identidades de los sujetos sexuados o legitima relaciones jerárquicas y de poder entre ellos, también ésta en la base de las cosmologías con las que las sociedades ordenan y explican sus costumbres, sus relaciones sociales y sus vínculos con la naturaleza, con el universo o con el otro mundo (HERITIER, 1994; 1998).

El cine de cabareteras comprende películas que ilustran la forma básica del incesto de segundo tipo así como otras que podrían considerarse variantes derivadas de la misma, en las que los parientes implicados en la relación triangular pueden ser afines (amigos, cuñados, madrastra-hijastra, concuñas) o consanguíneos en grados menos directos (tía-sobrina, tío-sobrino, medios hermanos).

Ejemplos del incesto clásico lo ilustran películas como La mujer del puerto y En carne viva. Si en la primera la protagonista, Rosario, una prostituta que trabaja en el cabaret de un puerto, encarnada por Andrea Palma, se ve involucrada en una relación amorosa con Alberto, un marinero que resulta ser su hermano, lo que desencadena el trágico final en el que ella se suicida arrojándose al mar, en la segunda Rosa Carmina encarna a dos personajes: Antonieta, una bailarina que tiene una hija con Fernando, un marinero que la abandona y provoca que ella se suicide, y Laura, hija de Antonieta y el marinero, quien ya adulta se convierte en cabaretera y se enamora de Arturo, hijo del marinero. Al saber que son medios hermanos ella va a suicidarse, pero a diferencia del film anterior, Arturo lo evita aclarando que es hijo adoptivo.

El incesto de segundo tipo está presente en sus más diversas modalidades en un significativo número de películas de cabareteras. En algunos casos, el incesto clásico de primer tipo puede combinarse con el incesto de segundo tipo, como en Amor salvaje, donde Rosa Carmina es una atractiva rumbera que va a vivir a Venezuela con sus tíos Antonia y Manuel. Éste y Alma se enamoran y Manuel, loco de celos, mata al joven Julio y a un marinero, pretendientes de la joven mujer fatal. Luego mata a su esposa Antonia y al final se suicida al no poder llevarse a Alma, quien se ha refugiado con un cura.

Otro ejemplo es el film Amor y Pecado, donde dos hermanos, Miguel y Raúl, comparten una misma pasión erótica por Teresa (Ninón Sevilla), hermana adoptiva de ambos. Ya adultos, Miguel, el mayor, trabaja en un cabaret para que Raúl estudie, y ambos cortejan a Teresa, quien decide comprometerse con Raúl. Al saberse rechazado, Miguel se vuelve drogadicto y Teresa se ve orillada a abandonar a Raúl para poder atender a su hermano y se convierte en cabaretera para poder mantenerlo. Sobrina, tío y tía, dos hermanos y una media hermana, en ambos casos el par incestuoso esta sobredeterminado por el triángulo incestuoso. 
En su forma típica, el incesto de segundo tipo está presente en películas clásicas como Trotacalles, en la que un Ernesto Alonso encarna a un proxeneta que se dedica a seducir y estafar a mujeres ricas. Vive a expensas de una prostituta (Miroslava) que resulta ser la hermana de la esposa de un millonario a la que Alonso hace su amante. La prostituta trata de prevenirla sobre quien es su amante pero su hermana no le cree. Cuando la pareja está por huir del país, la prostituta trata de detenerlos y el proxeneta la mata y a su vez él es abatido por la policía. La esposa rica es repudiada por su marido, y echada a la calle, se convierte en prostituta. El infeliz destino de las dos hermanas es aquí claramente referido a su común vínculo con la misma pareja sexual, como si el incesto, aunque sea por una vía indirecta, fuera una maldición que acarrea invariablemente la desgracia.

En Sensualidad, Ninón Sevilla es una cabaretera que, al salir de la cárcel, seduce al Juez que la condenó por robo. Este pierde la cordura por ella al grado de robar dinero de su despacho y arruinarse económicamente al ser robado por la cabaretera y su chulo. El hijo del juez la seduce para recuperar el dinero de su padre y el juez, al creer que estos son amantes y que piensan huir, golpea a su hijo y estrangula a la mujer, por lo que va a la cárcel. Con su toque de incesto de segundo tipo, el esquema de este film evoca sin embargo el modelo ya clásico del hombre maduro que es víctima de su obsesión por una joven ninfa y que recorre la historia de la literatura (desde El pelele de Pierre Louys a Lolita de Nabokov) y la cinematografía moderna (desde El ángel azul de Von Stenberg o La caja de pandora de Pabst hasta Lolita de Kubrick y Viridiana de Buñuel).

En Coqueta la protagonista, Marta (Ninón Sevilla), es una huérfana que trabaja en un cabaret, y vive en casa de Rubén, un pianista ciego encarnado por Agustín Lara. Luciano, quien la indujo a la vida de cabaretera y después la abandonó, regresa y le propone matrimonio, por lo que el ciego se da a la bebida. Sin embargo, Marta se enamora del hijo del ciego, Rodolfo, y cuando planean e intentan huir, después de golpear a Luciano, el ciego mata a Marta de un tiro. El fin trágico de la protagonista está una vez más conectado al registro de las pasiones desbordadas y desatadas por el vínculo incestuoso.

Un último ejemplo que ilustra el esquema del incesto de segundo tipo se da en Perdida, film en el que Ninón Sevilla es Rosario, una mujer pueblerina que fue violada por su padrastro y huye a la ciudad, donde se volvió prostituta. Don Pascual, un hombre adinerado, la sacó del burdel y le puso departamento pero después la echo del mismo por no prestarse a sus juergas. Un compositor la protege porque le recuerda a su esposa muerta, y ella debuta como bailarina en un cabaret. Se enamora del joven Armando y cuando le presenta a su padre, éste resulta ser Don Pascual, su ex amante, por lo que el romance termina en malos términos. Cuando descubre que un nuevo amante, un torero, está casado y no puede esperar mucho de él, ella se quita la vida.

En todos los ejemplos hasta aquí enumerados, el incesto de segundo tipo se manifiesta en una forma más bien típica. Sin embargo, existen otros filmes en los que el triángulo incestuoso, sin perder su fuerza trágica, es mucho más diluido y desdibujado, pues se da entre parientes afines o consanguíneos distantes. En Pecadora, por ejemplo, el triángulo incestuoso involucra a un hombre, una madrastra y una hijastra. Carmen (Ninón Sevilla) protege a Antonio, un traficante del que se enamora y con quien huye a la capital. El Dandy, proxeneta que explota a Carmen y la rumbera Leonor, los sigue y provoca que Carmen deje a Antonio y se case con Javier, un millonario, cuya 
hija Ana se enamora de Antonio. El Dandy mata a Javier pero Antonio lo entrega a la policía. Ana acusa a su madrastra Carmen de la muerte de su padre. Ella se da al vicio pero agonizante se reconcilia con Ana y Antonio y les desea felicidad.

Si bien María Félix no se apega al modelo típico de la cabaretera-rumberaprostituta sino a una de sus variantes más explosivas, la de la mujer fálica, bella, interesada y vengativa, que puede o no ser una prostituta, en varias de sus películas está presente el triángulo incestuoso en sus distintas versiones. En La devoradora, por ejemplo, el triángulo se da entre ella, un tío y un sobrino. El film narra a historia del joven médico Miguel, quien se entera de que su tío Antonio se va a casar con la cazafortunas Diana. Ella tiene un amante al que lleva al suicidio, y orilla a Miguel y Antonio a deshacerse de su cadáver. Después seduce a Miguel y acusándolo de acoso, pone al tío en su contra. Finalmente Miguel enfrenta a Diana y la mata, entregándose a la policía.

En Doña Diabla, por el contrario, el triángulo incestuoso es más definido e involucra a un hombre, una madre y una hija. La Félix encarna a una mujer decepcionada de su marido, al que abandona, y que convertida en una persona vengativa se dedica a seducir y explotar a los hombres que se cruzan en su camino. Educa a su hija Angélica en secreto para que ignore sus actividades, pero ella se entera de éstas al enamorarse de un amante de su madre. Cuando Angélica intenta huir con ese hombre, su madre lo mata y se entrega a la justicia.

En Pervertida el triángulo incestuoso, menos evidente, se da entre una mujer y dos amigos. Emilia Guiu representa a Yolanda, una mujer que se va del puerto en el que vive a la capital, con su padre y un hijo recién nacido, debido a que ignora el paradero de su novio, Fernando, quien huyo en un barco al creer que había matado a un usurero. En la ciudad ella se vuelve cabaretera. Fernando descubre que no mató al usurero y viaja a la ciudad a buscar a su mujer, donde su amigo Humberto se la presenta como su mujer, a la que ha sacado de la prostitución. Ella terminará por abandonar a Humberto y volver con Fernando

Una curiosa variante del incesto entre tres es el film Viajera, en donde la relación entre dos mujeres que comparten al mismo hombre no es de consanguinidad ni afinidad, sino que se establece debido a que una le cede a la otra la hija que concibe con la pareja sexual común. Rosa Carmina es una cabaretera ex amante de un profesor felizmente casado a quien reencuentra y de quien se embaraza. Obligada a matar a su proxeneta para salvar al profesor (el chulo quiere matar a éste para recuperar una joya que la cabaretera oculto en el saco del profesor, quien se la regalo involuntariamente a su esposa), después de purgar su condena cede su hija a la esposa del profesor que no había podido tener hijos, y desaparece.

Hemos señalado que la cuestión de la identidad, tanto psíquica como física, estructura muchas de las historias del cine de cabareteras. La inestabilidad, la metamorfosis, la duplicación o el olvido que afecta a la identidad mental o corporal se manifiesta en dichas tramas como un problema que generalmente padecen las mujeres protagonistas de estos melodramas, y que puede estar conectado en mayor o menor medida al triangulo incestuoso.

Un ejemplo logrado de esta articulación es el film La bien pagada, en donde María Antonieta Pons encarna a una mujer desdoblada en esposa y amante del mismo hombre. Pons es en este film Carola, una mujer frívola y seductora, que se casa con un millonario, Fernando, a quien traiciona con un 
amante. $\mathrm{Al}$ enterarse, éste obliga a su mujer a renunciar a todos sus derechos y se va de viaje, y al volver se entera que Carola es bailarina y se prostituye con hombres adinerados. Este comienza a frecuentarla como cliente y arrepentida, ella quiere volver con su ex marido, a quien descubre que ama, pero éste solo la trata como una prostituta. Cuando Fernando esta por casarse con una hermana de ella, Carola enferma y muere en brazos de él, quien se da cuenta de cuanto la ama.

El fantasma masculino de la mujer escindida alcanza en este film una expresión ejemplar, siendo la misma mujer del mismo hombre quien se desdobla en esposa y amante, mujer legal e ilegal, santa y puta, objeto de veneración y desprecio, cambiando su valor libidinal y moral en función de su cambio de estatus. El triángulo sexual con la hermana de Carola comprueba la eficacia trágica del incesto de segundo tipo, pero aquí opera como un telón de fondo que sobredetermina otro triángulo erótico, el que establece Fernando con su doble mujer, la misma y otra para su pareja sexual.

Otra variante bastante notable del fantasma masculino de la mujer dividida se despliega en el film Sucedió en México, en el cual María Antonieta Pons es una mujer que intenta suicidarse arrojándose al mar debido a las infidelidades de su marido Mauricio, pero fracasa. Habiendo quedado desfigurada, un cirujano la opera y cambia completamente su apariencia. Como su marido piensa que su esposa huyó de él y se fue con una hermana que él no conoce, ella, aprovechando su metamorfosis corporal, se hace pasar por su hermana bailarina, llegada de Europa. Creyéndola su cuñada, Mauricio la corteja y la convierte en su amante, le ofrece el dinero que es de su mujer y viaja con ella. Cuando se entera que su esposa ha vuelto, el esposo se compromete a reconciliarse con ella pero después le propone a su supuesta cuñada engañarla, y ésta, decepcionada, lo abandona.

La misma mujer es aquí la encarnación de dos hermanas que comparten un mismo compañero sexual, y el hombre trata de esposa y de cuñada a una mujer que es la misma y otra. La fantasía neurótica masculina no puede expresar mejor en términos cinematográficos su percepción de la mujer como un ser dual, una mujer que resulta inatractiva en tanto que esposa devota pero que es enloquecedora e irresistible en tanto que amante (y doblemente enloquecedora si es cuñada).

Los desdoblamientos o las identidades ocultas están también muy presentes y juegan un papel central en varios filmes clásicos en donde los referentes incestuosos son menos evidentes, como en Aventurera, en donde Ninón Sevilla es una prostituta que aparenta ser una decente novia para un joven millonario, que es el hijo de una perversa lenona de la que ignora sus actividades y a la que cree una madre virtuosa y moralmente intachable. En el universo del melodrama cabaretero, las apariencias, la simulación y el camuflaje son un recurso del que se valen frecuentemente sus protagonistas, y los hombres suelen ser personajes que creen saber pero que ignoran todo sobre las mujeres que los rodean, hasta que llega el momento, como en este film, en el que la verdad se revela y las cosas cambian radicalmente.

Es el caso de la historia de Un cuerpo de mujer, donde Javier, el joven discípulo de un famoso pintor, Raúl, ignora que éste es su padre y que uno de sus cuadros, una mujer desnuda pero cuyo rostro ha sido arrancado, es el retrato de su propia madre, a quien el considera una santa. Al investigar la historia del retrato, por el que está obsesionado, el se entera que Raúl vivió con 
una tal Rosa, quien aparentemente lo abandono por Aguilar, mecenas del pintor, y terminó de cabaretera. Javier descubre que Aguilar no anduvo con Rosa, y que ésta dejo a Raúl para que pudiera triunfar como pintor. Pero Javier ignora que su propia madre es Rosa, que ésta le oculta la verdad sobre su pasado como rumbera, y que ella destruirá la pieza faltante del cuadro que está por recibir su hijo, a fin de que éste no se entere de la realidad de las cosas.

En algunos casos, la identidad, más que ocultarse o aparentarse, puede perderse y recuperarse, como en Aventura en Río, donde Ninón Sevilla es Alicia, una mujer felizmente casada y con una hija, que viaja con su marido a Río de Janeiro. Allí, a causa de un accidente ella queda amnésica y un proxeneta que la encuentra la convierte en cabaretera y la obliga a trabajar para él, haciéndole creer que ella se llama Nelly y que es una prostituta. Su marido la cree muerta, pero un amigo de éste reconoce a Nelly en el cabaret y le avisa al esposo. Cuando se encuentran, Alicia no lo reconoce, pero al ver a su hija se desmaya y al volver en sí recuerda todo, menos su vida de cabaretera. El olvido de su episodio como cabaretera, que resulta por demás absurdo, tiene aquí una clara connotación sexista que evoca el fantasma masculino de que toda mujer "decente" es o puede ser una prostituta en potencia. En otros casos, es la identidad de los hombres con los que se relaciona la que es ignorada por las mujeres. En la Hija del penal, por ejemplo, Maria Antonieta Pons es una joven que sale del penal en el que vive cuando su madre convicta muere, y que va a trabajar en el cabaret de un mafioso, Aranzuela, de quien ignora que es su padre. Ernesto se enamora de ella, se enrola en la banda de Aranzuela y al fracasar en un golpe, es detenido y encarcelado. Maria, embarazada, lo sigue a la cárcel. Ella denuncia una tentativa de evasión para salvar a Ernesto de una muerte segura. El dueño del cabaret es detenido y ellos salen libres, y Ernesto, quien se entera que Aranzuela es el padre de Maria, se lo oculta a ésta.

Una variación de este esquema es el del film As Negro, en el que están implicados dos hermanos gemelos en un triángulo incestuoso. En este film se narra la historia de unos hermanos gemelos que acuerdan desde que son niños su destino. Uno se dedicará a la medicina, el otro se dedicará a los negocios ilícitos para ayudarlo a estudiar en la Universidad. Éste último enamora a una cabaretera (Meche Barba), se involucra en un asalto y entrega el botín obtenido al hermano para que estudie una especialidad en enfermedades tropicales en los Estados Unidos.

La cabaretera convence a su amante de entregarse a la policía y purgar su condena. Años después, cuando el hermano médico regresa al país, el otro se evade de la cárcel para verlo. Sus socios en el asalto, que lo buscan para reclamar el botín, confunden a su hermano con él y lo matan. El prófugo hace creer a la cabaretera que murió y que él es su hermano gemelo. La esposa del médico va a su funeral y su gemelo le cuenta la verdad y le propone hacerse pasar por su hermano a fin de culminar las investigaciones que éste llevaba a cabo para producir una importante vacuna. El prueba la vacuna en sí mismo y enferma gravemente, y antes de morir, informada de la verdadera identidad del falso médico, la cabaretera lo ve por última vez antes de que éste fallezca en sus brazos. 


\section{La modernidad y sus iconos}

Es muy importante destacar que la mayor parte de las películas aquí reseñadas han sido dirigidas por cineastas hombres, y que los guiones de estos filmes han sido escritos en su mayoría por hombres, entre los cuales se encuentran muchas de las mejores plumas de la época (José Revueltas, Mauricio Magdaleno, Luis Spota). La mirada que domina en estos filmes es por ello una mirada de género que privilegia los deseos y los fantasmas inconscientes masculinos sobre las mujeres.

Dadas las condiciones de la industria fílmica mexicana de los años cuarentas y cincuentas, que hacía impensable la existencia de mujeres realizadoras, el cine de cabareteras fue un cine hecho por hombres, pensado para y dirigido especialmente a un público masculino, lo que no excluía para nada su consumo por parte de las mujeres. La excepción a esta regla fue el caso de Matilde Landeta, la única directora de cine de esta época, pionera de un cine con perspectiva femenina que en dos de sus películas, Lola Casanova, de 1948 (que relata la historia de una mujer criolla casada con un indígena e involucrada en la lucha de resistencia del pueblo Seri en la época porfirista) y La negra Angustias, de 1949 (que trata de una coronela de la época de la revolución que comandó grupos rebeldes de filiación zapatista) desarrolló una mirada de género que otorgó a la mujer un protagonismo y un perfil inéditos $\mathrm{y}$ excepcionales en la cinematografía mexicana ${ }^{8}$.

Con todo, su tercera película, Trotacalles, de 1951, la más conocida y la más exitosa comercialmente, está plagada de las fórmulas y los esquemas narrativos presentes en la mayor parte de las películas de cabareteras hechas por hombres (el guión del film, en efecto, es de Luis Spota). De hecho, este es el film que ilustra en su forma más pura el fantasma masculino asociado al triángulo erótico propio del incesto de segundo tipo, en este caso entre un hombre y dos hermanas, y no es para nada indiferente el hecho de que lo haya dirigido una mujer. En una época en que la sexualidad era muy reprimida, las relaciones de género muy desiguales y la cultura patriarcal y machista muy arraigada, era impensable que el cine de prostitutas y cabareteras, incluso el realizado por una mujer de ideas progresistas, pudiera ir más allá del horizonte falocéntrico y masculino desde el que se codificaba lo erótico en el cine.

El cine ha creado iconos muy diversos de la mujer y de la feminidad, en función de los géneros o de los escenarios en los que sitúa sus historias. Como lo muestran estudios recientes (RODRÍGUEZ FERNÁNDEZ, 2006), aunque en la mayoría de los casos la mujer ha sido imaginada desde la mirada y el deseo masculino, las figuras de la mujer salvaje que aparece en el western o de la mujer exótica del cine de aventuras (aquel que se pasa en las islas del pacífico o en el África negra) son muy distintas de las figuras de la mujer buena e ingenua de la comedia musical, de la mujer malvada y seductora del cine negro o de la que aparece como víctima en el cine de terror o en el thriller psicológico.

La cabaretera, rumbera o prostituta que puebla el cine mexicano aparece en éste género, como lo hemos visto, como una figura ambigua y enigmática, a la vez subversiva y condenada por la fatalidad, amenazadora y fascinante, una mujer cuyos innumerables atributos negativos (caída, perdida, de la mala vida,

\footnotetext{
8 Detalle curioso, la protagonista del film Lola Casanova fue la actriz Mercedes Barba, figura consagrada del cine de rumberas, quien realiza aquí un excepcional papel dramático y con un fuerte contenido político, en un entorno ajeno por completo al mundo de la prostitución y el cabaret.
} 
de la calle, sin alma, de la noche, del arrabal, pecadora, coqueta, vendida, hipócrita, salvaje, aventurera) son los de un ser incierto y carente, marginal y anti-social. Un ser que tiene como su contraparte fílmica a la madre, esa mujer buena, sumisa, comprensiva y sacrificada que puebla el imaginario del melodrama familiar a la mexicana, pero que es también una mujer terrorífica, pues como dice Salvador Elizondo "el terror de la madre nos empuja cada vez con más furia hacia los brazos de la ramera. Esta es, casi siempre, la madre fallida" (GARCÍA y MACIEL, 2001: 223).

En todo caso, ella está emparentada con un icono de lo femenino que desde siempre habita en el imaginario colectivo: la mujer fatal, aquella que lleva al hombre a la ruina o a la muerte, manipuladora, sensual y seductora. La mujer fatal es un arquetipo que está presente en la mitología clásica (Pandora, Circe, Medusa, las Sirenas) y en la tradición judeo-cristiana (Eva, Lilith, Salomé) y que el cine ha sabido recrear, adaptando su imagen a los marcos culturales de la modernidad, acercándola así al gran público.

En el cine negro, género en el que se convirtió en un personaje característico, la mujer fatal es una suerte de ángel del mal que está siempre asociada a la destrucción y la desgracia, a la sed de poder y a la violencia. Sin embargo, en sus expresiones canónicas, Joan Bennet en Perversidad (Fritz Lang, 1945), Lana Turner en El cartero siempre llama dos veces (Tay Garnet, 1946), Jane Greer en Retorno al pasado (Jacques Tournier, 1946), Rita Hayworth en Gilda (1946) o Bárbara Stanwyck en Perdición (Billy Wilder, 1948), la mujer fatal puede ser una mujer fría, malvada y sin escrúpulos, dominante e irresistible, que manipula a los hombres y representa un riesgo para su vida, pero rara vez es una prostituta, una cabaretera o una "callejera".

En el cine de cabareteras mexicano, si bien las protagonistas poseen algunos de los atributos de la mujer fatal, como la ambigüedad, la simulación o el carácter enigmático, el énfasis está colocado en su condición de prostituta y bailarina, en el goce erótico que su cuerpo provoca al bailar, en su desenfreno y libertad sexual o en la amenaza que representa para las instituciones burguesas (la familia, la iglesia, el orden judicial). Como la mujer fatal, el personaje de la prostituta en el cine mexicano desafía las normas y el control masculino, da rienda suelta a sus deseos, y al final recibe un castigo (la muerte, la cárcel o la enfermedad) convirtiéndose en víctima de sí misma y pasando de una condición activa a una pasiva.

Sin embargo, la mujer fatal es un personaje que resulta más aceptable o con el cual puede identificarse más fácilmente una mujer, a diferencia de la prostituta, un sujeto estigmatizado y menos atractivo. En el cine negro, por lo demás, la mujer fatal es un personaje entre otros, y no todos los filmes de este género se centran en ella, mientras que en el cine mexicano de cabareteras éstas son en casi todos los casos el personaje principal.

En México el gusto por los bajos fondos, las prostitutas, el burdel y el ambiente nocturno no solo es una obsesión popular, como lo hemos destacado, también es un interés culto que se remonta a la literatura decadentista mexicana que florece a fines del siglo diecinueve y comienzos del veinte (Julio Ruelas, Rubén M. Campos, Efren Rebolledo, Jesús Contreras, Federico Gamboa). Dicho interés está muy relacionado con un esquema ideológico decimonónico pero que ha sobrevivido a su tiempo, que oponía el mundo civilizado de la corrección y las buenas maneras al mundo salvaje del prostíbulo y la disipación, y que concebía al hombre como un ser autónomo y racional, capaz de controlar sus instintos, 
por oposición a la mujer, habitada por el deseo animal e inclinada por naturaleza a la lujuria. El personaje de Santa, arquetipo de la mujer caída y referente mayor del cine prostibulario, encarna a esta mujer inocente pero habitada por el deseo y un instinto animal incontrolado, que una vez que es seducida y despierta a su sexualidad, queda condenada a perderse en el placer asociado a la misma, más allá del remordimiento y la culpa (VÁZQUEZ MANTECÓN, 2005: 47)

Pero como hemos visto, el modelo de la prostituta pasiva y victimizada tiene como contraparte un modelo en el que ésta aparece como un sujeto activo y autosuficiente. En este otro sentido, la prostituta fue motivo de imágenes finiseculares creadas por escritores (Baudelaire, Zola, Walter Benjamin, George Simmel) y pintores (Degas, Manet, Toulouse Lautrec, Cezánne) que la convirtieron en un ícono de la modernidad, representante de la monetarización y la comercialización de las relaciones sociales, pero sobre todo de la capacidad de las mujeres para sobrevivir de manera independiente. Como señala Vázquez Mantecón, la prostituta es pensada en esta época como la expresión más amenazadora de la mujer trabajadora. Junto a las costureras, las modistas y las meseras, las prostitutas encarnan a las mujeres libres, dotadas de una independencia económica que es también una independencia moral, y que generan desconfianza y ambivalencia en los hombres. Mujeres trabajadoras que escritores mexicanos como Ángel del Campo, Emilio Rabasa o Efrén Rebolledo evocarán como un motivo literario en sus obras (VÁZQUEZ MANTECÓN, 2005: 50).

Ambas figuras de la prostituta, como hemos intentado mostrar, no solo perviven y están en el origen del cine nacional, también alcanzan su mayor proyección y popularidad en el cine de los años cuarenta y cincuenta en la medida que ellas son la expresión del sujeto de la modernidad, en una época en la que se experimentan en México las profundas transformaciones que acarrea la vida urbana. La prostituta, sujeto complejo, desarraigado y cosmopolita que vive en un mundo incierto y de alto riesgo, al límite de las normas, sujeto escindido y metamórfico, sujeto del cambio que se sitúa en el lado oscuro, nocturno y sombrío de la Babel urbana, es así el icono cinematográfico por excelencia de la modernidad mexicana.

Pero ella es dicho icono en la medida en que también es, no lo olvidemos, la depositaria de estructuras mentales de larga duración que remiten a lo inconsciente y lo reprimido cultural. Las metáforas del incesto en sus modalidades de primer y segundo tipo juegan un papel clave en su definición, pues no solo tejen y estructuran las diferentes variaciones narrativas del género cinematográfico en donde la prostituta aparece como un ser polimorfo, múltiple, sujeto a toda clase de desdoblamientos. Generadora de fatales confusiones dramáticas, simbólicas y eróticas, escenarios para el goce fílmico y la trasgresión imaginaria, la mujer de la calle es a la vez el objeto de las fantasías eróticas más arraigadas en la psique masculina del mexicano y la encarnación moral de los traumatizantes mitos de origen de la identidad nacional, poblados de mujeres violadas, vendidas y prostituidas. 


\section{Bibliografía}

AVIÑA, Rafael. Una mirada insólita. Temas y géneros del cine mexicano. Océano, México, 2004.

BARTRA, Roger. La Jaula de la melancolía. Grijalbo, México, 1987.

BREDER, Débora. Entre o "indizivel horror da procriacao" e a "sexualidade androide": notas sobre The Brood e Crash de David Cronenberg. Devires, 6 (2). Belo Horizonte, Julio-Diciembre, 2009.

A incestuosa gemeidade: notas sobre A Zed and two noughts, de Peter Greenaway. Devires, 8 (1) Belo Horizonte: UFMG. Jan.-Jul., 2011.

DE LA MORA, Sergio. Cinemachismo. Masculinities and sexuality in Mexican film. University of Texas. Austin, 2006.

ELIZONDO, Salvador. "Moral sexual y moraleja en el cine mexicano". En: Gustavo García y Daniel Maciel (comp.). El cine mexicano a través de la crítica. UNAM, 2001.

HERITIER, Françoise. Masculino/Femenino. El pensamiento de la diferencia. Editorial Ariel, Barcelona, 1998. . Les deux soeurs et leur mere. Odile Jacob, Paris, 1994.

OROZ, Silvia. "La mujer en el cine Latinoamericano". En: Memoria del XI Festival Internacional del Nuevo cine Latinoamericano. UNAM, 1990.

RAMIREZ BERG, Charles. Cinema of solitude. A critical study of mexican film 1967-1983. University of Texas Press, 1992.

RODRÍGUEZ FERNÁNDEZ, María del Carmen. Diosas del celuloide. Arquetipos de género en el cine clásico. Ediciones Jaguar, Madrid, 2006.

SAND, Shlomo. El siglo XX en pantalla. Cien años a través del cine. Crítica, Barcelona, 2005.

TUÑON, Julia. Mujeres de luz y sombra en el cine mexicano. La construcción de una imagen, 1939-1952. El Colegio de México e Imcine, México, 1998.

VÁZQUEZ MANTECÓN, Álvaro. Orígenes literarios de un arquetipo fílmico. Adaptaciones cinematográficas a Santa de Federico Gamboa. UAM-A, México, 2005 . 